\title{
Commodifying Teacher Learning to Recruit: A Needs Analysis of Utah's Teaching as a Profession Curriculum
}

\author{
William J. Davis
}

Southern Utah University

\begin{abstract}
Author Note
William J. Davis (iD https://orcid.org/0000-0002-7803-8311

Correspondence concerning this manuscript should be addressed to William J. Davis,
\end{abstract} Southern Utah University, Department of Teacher Education, 351 W. University Blvd., Cedar City, UT 84720. Email: williamdavis2@ suu.edu 


\begin{abstract}
Drawing from the State of Utah's Teaching as a Profession strands and standards documents, along with documents, web sites, and videos from supporting organizations like Educators Rising and its parent entities, this intrinsic case study sought to surface the perceived and relative teacher learning needs Utah's curriculum developers appear to hold for secondary students interested in teaching and education careers. Six central teacher learning needs were identified in the study: 1) learning about the teaching profession; 2) developing a standardized vocabulary for education and teaching; 3) understanding teaching as a cycle with measurable outcomes; 4) producing teaching materials; 5) cultivating teaching skills, and 6) identifying difference in/between students. The study includes a discussion of the above needs and how the state and its partners have commodified early teacher learning by encouraging narrow, technical view of such learning while also promoting participation in a marketplace for educational credentials.
\end{abstract}




\section{Commodifying Teacher Learning to Recruit: A Needs Analysis of Utah's Teaching as a Profession Curriculum}

Although teacher shortages amid the COVID-19 pandemic have exacerbated staffing challenges (Gecker, 2021, September 22), school systems struggled during the previous decade to offset significant declines in teacher education enrollment before the pandemic began (Sutcher et al., 2019). Mirroring teacher staffing challenges across the US, as well as the renewed emphasis nationally upon teacher retention and recruitment (Sutcher et al., 2019), the State of Utah has promoted various initiatives to keep and to recruit teachers, including salary increases and pipeline programs for paraprofessionals to become teachers (Aguilar, 2020, February 4; Smith \& Ho, 2019, August 23). In addition, the state has established curriculum standards for grades 9-12 teacher career exploration courses called Teaching as a Profession (hereafter referred to as $T A P)$. In effect, the TAP courses, along with initiatives implemented in other states like teacher academies (e.g., Audrain \& Googins, 2020) and other grow-your-own programs (e.g., Goings \& Bianco, 2016), have extended both teacher preparation and neo-liberal forces into secondary schools. Despite this expansion, little is known of the particular learning needs of the pre-collegiate student who is learning to teach (Davis, 2021a), even though K-12 experiences are regarded as deeply influential in teacher learning (Lortie, 1975/2002). The purpose of this exploratory, intrinsic case study is to investigate Utah's TAP courses to better understand the teacher learning needs curriculum developers apparently attribute to secondary students interested in teaching and education careers.

\section{Theoretical Framework}

\section{Teacher Shortages and Recruitment Initiatives}


K-12 school systems have periodically dealt with acute teacher shortages, with some journalists and scholars characterizing the challenges brought about by COVID-19 as a crisis point for the teaching profession. Since the 1990s, politicians and school leaders in many states have faced cycles of teacher demand and supply challenges (Barry \& Shields, 2017). Though staffing challenges in the 1990 s were primarily due to high attrition rates among teachers (Barry \& Shields, 2017), a new challenge in the late 2000s intensified the problem: declining teacher education enrollments. The supply of teachers was heavily impacted by the $35 \%$ decline in teacher preparation program enrollments between 2009 and 2014, with $23 \%$ fewer candidates completing programs during this period as well (Sutcher et al., 2019). As school districts sought to hire teachers as the impact of the Great Recession partially subsided, qualified teachers were difficult to find. Consequently, pre-pandemic estimates suggested that the annual teacher shortage would surpass 100,000 by 2018 (García \& Weiss, 2019; Sutcher et al., 2019). Recent analyses suggest the COVID-19 pandemic's impact on teacher attrition and mobility will be modest (e.g., Goldhaber \& Theobald, 2021), yet the ongoing inability of schools to find qualified teachers continues to make teacher recruitment initiatives a pressing concern for $\mathrm{K}-12$ schools (Carver-Thomas et al., 2021; Gecker, 2021, September 22).

School systems have responded to teacher staffing challenges with a complex web of recruitment and pipeline initiatives, becoming more aggressive with their responses in recent years (Gecker, 2021, September 22). Incentives like fellowships, grants, tax credits, and loan forgiveness have been used to draw applicants to the teaching profession, yet Berry and Shields (2017) noted that states like California had discontinued these initiatives by the early 2010s. In other states, incentive programs continued or were started, including salary increases (e.g., Smith \& Ho, 2019, August 23). Another series of initiatives to recruit teachers can be described as 
grow your own (GYO) programs, which seek to provide pathways for different groups (e.g., paraprofessionals, secondary students) to pursue teaching careers in their home communities (Aguilar, 2020, February 4; Gist et al., 2019). Secondary-based (i.e., middle and high schoolbased) teacher pipeline programs like teacher academies have existed since the 1950s (Audrain \& Googins, 2020). An increase in pre-collegiate teacher recruitment initiatives in the 1980s saw a number of secondary-level programs develop in the southeast and southwest regions of the US, both areas that have historically struggled with teacher shortages (Bolich, 2003; Recruiting New Teachers, 1993). Despite the potential attributed to such pipeline programs, particularly for recruiting teachers of color, scholarship on GYO programs has been described as "minimal" (Gist et al., 2019, p. 13).

\section{Pre-collegiate Teacher Learning}

The literature on middle and high school GYO programs is minimal not just in amount but due to its neglect of the secondary school student as a distinct and unique learner when it comes to learning to teach. Using Lortie's (1975/2002) apprenticeship of observation - the 13,000 hours students spend watching and interacting with their own teachers as studentsteacher educators continue to frame pre-collegiate teacher learning as a process of socialization (e.g., Cancino et al., 2020; Collet \& Greiner, 2020; Grey, 2020). Despite its longevity and popularity as an explanation of pre-collegiate teacher learning (Adams et al., 2021), the apprenticeship of observation has been criticized by a number of scholars (e.g., Davis, 2021a; Knapp, 2012; Mewborn \& Tyminski, 2006; Smagorinsky \& Barnes, 2014). Two of these critiques directly relate to secondary school students' school experiences and GYO programs. First, the expectations and singular events of this present era (e.g., the COVID-19 pandemic) have led scholars to posit that the apprenticeship of observation for this era's teachers may yield 
fundamentally different learning about the role and work of professional teachers (Hargreaves \& Fullan, 2020; Smagorinsky \& Barnes, 2014). Second, teaching experiences available to young people today_-including teacher academies and high school internships and courses, but also early work, athletic coaching, and volunteer experiences - allow many young people to teach on their own in various contexts (Davis, 2021a). Scholarship examining secondary-level GYO programs tends to avoid issues of teacher learning, instead focusing on the benefits, standards, and/or structures of these programs (e.g., Audrain \& Googins, 2020; Bianco \& Marin-Paris, 2019; Goings \& Bianco, 2016).

Existing literature on programs like teacher academies and Pathways2Teaching exemplifies this focus, articulating the downward creep of professional teaching and college/workforce expectations. For example, Audrain and Googins (2020) offered a broad description of teacher academies as a GYO program, which they claim enrolled approximately 150,000 students across the US. Audrain and Googins (2020) lauded the role of Educators Rising, an organization recognized by the US Department of Education as a career and technical education program; drawing on the AACTE's Clinical Practice Commission report, they argued that clinical practice along with the Educators Rising standards for pre-collegiate students should be the basis of a new form of teacher academy. In her description of the Pathways2Teaching program, Bianco (2019) also described field experiences in clinical settings, along with "a strong emphasis on college access and readiness skills" (p. 39). Although the literature on secondarylevel GYO programs is in its infancy, standards and college/workforce readiness - along with the potential benefits of recruiting teachers earlier-most often appear to be emphasized in scholarship. In effect, the demands of college study and the professional teaching role have been used to establish the curricular frameworks for these GYO programs. 


\section{Using Teacher Learning Needs Analysis to Study Curricula}

The purpose of this study is to analyze the curriculum and artifacts of a particular GYO program using an adapted form of needs analysis or assessment, an approach more commonly utilized in English language teaching to collect and analyze learning data to formulate goals and instructional approaches (Sumarsono et al., 2017). Needs analysis generally is employed early in curriculum development; Iwai et al. (1999) described needs analysis as something done informally by teachers to determine what their students need to learn next. Defining need is a central activity in any needs assessment, though one complicated by the subjectivity of needs for a given task or a context: defining need means determining "who needs what, as defined by whom” (Berwick, 1989, pp. 52-53). According to Berwick (1989), a key distinction in needs analysis is felt versus perceived needs; felt needs involve learners' own notions of what they need, whereas perceived needs include "judgments of certified experts about the educational gaps in other people's experience” (p. 55; c.f., “normative needs” in Kettner et al., 2008, p. 10). Needs may differ based on contextual factors as well (Kaewpet, 2009), which Kettner et al. (2008) have defined as relative needs, or the "needs and resources in one geographic area compared with needs and resources in another" (p. 10). Unlike its use in English language teaching, this study employs needs analysis to analyze an established curriculum.

To engage in this analysis, this study adapts Berwick’s (1989) and Kettner et al.'s (2008) descriptions of needs analysis to analyze perceived and relative teacher learning needs embedded within the curriculum artifacts of Utah's TAP courses. Scholars, policymakers, and educators have long debated a wide array of teacher learning needs for preservice and professional teachers. These needs include cultivating various forms of knowledge (e.g., Shulman, 1987), challenging beliefs (e.g., Douglas, 2019; Holt-Reynolds, 1992), developing multicultural 
competencies and praxis (e.g., Durand \& Tavaras, 2020), and utilizing discrete instructional and behavioral management strategies (e.g., Boz \& Boz, 2007), among others. The preceding list, rather than exhaustive, reflects the array of needs particular to teacher learning. The goal of this study is to surface the teacher learning needs embedded in Utah's TAP courses by their developers, who are assumed to possess expertise in teacher learning and preparation. The following overarching research question has guided this inquiry: What perceived and relative needs are stated or evident in the curricular artifacts of one state's secondary school-based teacher career exploration courses?

\section{Method}

This study is an exploratory, intrinsic case study utilizing document analysis. Intrinsic cases are those that researchers are interested in, "not because by studying it we learn about other cases...but because we need to learn about that particular case" (Stake, 1995, p. 3). Case study research can utilize a wide array of data sources, including non-technical sources (Bowen, 2009). Bowen (2009) asserted that document analysis's utility in analyzing a variety of sources makes it a particularly appropriate research method for case study research.

\section{Study Context}

The focal case under examination is the American state of Utah, specifically the state's efforts to develop and maintain teacher career exploration courses in support of its K-12 career pathway. Career Pathways in Utah are developed by the state's Career and Technical Education (CTE) office to "show students a direct connection between doing well in high school and being able to transition smoothly to postsecondary opportunities or getting a good job when they graduate." For at least four years, the CTE office has maintained a series of curriculum standards for three separate courses intended for secondary school students who are considering education 
and teaching careers. These classes are offered by individual high schools that choose to provide some or all of the classes, taught by credentialed teachers who may also possess a special teaching endorsement to teach the classes. A brief overview of each class is provided below.

\section{Teaching as a Profession 1}

The stated goal of TAP 1 is "to introduce students to the role and positive influence of an effective educator." During the course, students are expected to explore careers in education and learn how to make themselves more competitive for employment. In addition, students are asked to learn about multiculturalism and diversity, as well as instructional strategies and classroom technologies. Students pursue these topics through performance-based assignments like interviews with educators, essays, and a 5-7-minute lesson plan.

\section{Teaching as a Profession 2}

Building on TAP 1, the TAP 2 course is intended "to introduce students to career opportunities and the required credentials needed to be a qualified educator." Students are asked to expand on their understanding of multiculturalism and diversity by using principles of the two, along with educational theories, to create instructional materials. To demonstrate their understanding of the course's principles and theories, students perform additional performance skills, such as creating visual artifacts that illustrate educational theories, an artifact exploring personal cultural biases, and a 15-minute lesson that includes a lesson plan, activity, formative/summative assessments, and a final reflection on the lesson.

\section{Teaching as a Profession 3}

The final class in Utah's K-12 career pathway, TAP 3, is intended to move beyond career exploration to "familiarize students with professional expectations and responsibilities of an educator." Performance skill demands also increase in complexity, with students asked to create 
a unit plan portfolio that includes lesson plans, formative and summative assessments, classroom and emergency plans, and other resources. TAP 3 is sometimes offered by Utah universities as a concurrent enrollment course, which allows students to earn credit both for a high school course at the same time as they earn college/university credit with an affiliated higher education institution (Auck \& Suddreth, 2019).

\section{Educators Rising}

Utah's K-12 education pathway is closely tied to the work of a separate, nongovernmental entity called Educators Rising. Administered by PDK International and Curriculum Management Solutions, Inc., Educators Rising is a nationwide organization that claims to employ "a community-based model" to enhance teacher recruitment. Schools across Utah and other states are encouraged to maintain their own Educators Rising chapters, where faculty — typically CTE teachers — advise students and supervise their participation in Educators Rising events. Utah teachers seeking an endorsement to teach the TAP courses are required to complete training as an Educators Rising advisor and participate in the state's CTE summer conference, which itself includes several modules related to Educators Rising.

\section{Data Sources}

This case study draws from a number of sources and document types, which can be grouped into four broad categories: 1) curriculum standards, 2) state government web sites and documents, 3) non-government web sites and documents, and 4) videos. Curriculum standards

include the strands and standards documents for each TAP course. The standards were available for download from the Utah Education Network and the Utah CTE web sites. I reviewed these web sites for other pages and documents that might be relevant to my inquiry. In addition, I reviewed web sites and documents from non-government web sites, including the Educators 
Rising and Curriculum Management Solutions, Inc. web sites. I also viewed videos from YouTube that were linked to the government or non-government web sites.

\section{Data Analysis}

All documents were stored and organized in a single project using QSR's NVivo 12 qualitative data analysis software. Initial coding drew from Berwick's (1989) and Kettner et al.'s (2008) descriptions of perceived and relative needs. All data were coded using the provisional codes (Saldaña, 2016) of perceived teacher learning needs and relative teacher learning needs. The source of each document was coded as a case as well (e.g., Educators Rising). Following a series of analytic memos to probe the initial coding for patterns (Birks et al., 2008), a subsequent round of coding was conducted. This round of coding sought to more thoroughly examine patterns across data sources, utilizing process coding (Saldaña, 2016) to isolate specific actions high school students were expected to take in order to learn to teach. As additional codes were developed, analytic memoing was utilized to further examine the new codes and any processoriented patterns that could be triangulated across data points (Birks et al., 2008). Once coding solidified into fixed categories, these categories were outlined and briefly described in a memo.

Two external audit approaches were utilized to enhance the trustworthiness of the study's findings. First, preliminary findings were submitted for presentation at regional and nationallevel education conferences; the findings were subjected to blind peer-review prior to the conference (see McGloin, 2008), as well as additional critique within presentation sessions. After incorporating feedback from peer reviews and conference presentations, a revised findings memo and a draft of the manuscript were shared with a critical friend (see Miles \& Huberman, 1994) well versed in teacher education literature but not this particular study. Critiques were examined 
in a final series of memos, and changes were made to the findings memo and manuscript based on this feedback.

\section{Findings: Teacher Learning Needs in Utah's Teacher Career Exploration Courses}

In the following section, I outline the perceived and relative teacher learning needs I surfaced through the study's analytical procedures. Headings offer a short description of the need. Each section includes descriptions that draw from multiple sources analyzed as part of the case study.

\section{Learning about the Teaching Profession}

As might be expected given the above descriptions of the TAP standards, there is an emphasis in the standards - particularly in the first two courses in the sequence — on learning about roles, legislation, and policies related to the teaching profession. For example, both the TAP 1 and TAP 2 standards ask students to "explore career options" related to education, including the roles of superintendent, principal, assistant principal, core subject teachers, and non-core subject teachers. The key difference between the courses is emphasis; whereas TAP 1 students are asked to explore "employability skills needed for gaining and maintaining employment" in educational roles, TAP 2 students must explore "salaries, required degrees, endorsements, and certifications needed for each position," information that is to be gathered from the Utah State Board of Education (USBE) Licensing web site. The TAP 2 standards also call for student exploration of the Utah Effective Teaching Standards, the USBE's health, safety, security, and emergency procedures, as well as the Local Education Agency (LEA) Emergency Compliance and Assurance form that "outline[s] the requirements for an Emergency Preparedness and Emergency Response Plan." 
Although the TAP standards direct students to examine USBE requirements, policies, and procedures, the standards also call for students to examine organizations and influences on the teaching profession beyond Utah. Advocacy and professional organizations are a focus in the TAP 2 standards, which includes a list of national organizations and their regional or state affiliates (e.g., American Council on Teaching a Foreign Language [ACTFL]; Utah Foreign Language Association [UFLA]). Another influence students are asked to review and explore in the TAP classes is legislation and court cases. For example, the TAP 1 standards focus on legislation related to "special populations," such as the Individuals with Disabilities Education Act. In TAP 2 courses, students are expected to explore "landmark court cases" like Brown vs. Board of Education of Topeka, KS and the Title IX of Education Amendment Act, culminating in a research-based presentation on court cases. Whether the source or event is related to Utah, the standards suggest that a teacher must be at least somewhat familiar with the roles, organizations, and legal influences that shape the role of a professional educator.

\section{Developing a Standardized Vocabulary for Education and Teaching}

However, much of the learning students are expected to engage in related to the teaching profession and how to teach is focused on defining events, places, functions, and processes related to professional education careers. As one reviews the TAP standards, the word define is frequently encountered. In the TAP 1 standards, 55 terms including "social factors," "lesson plan," and "underachievement" are set off in bold face, providing teachers succinct definitions they will presumably give to students through their teaching and assessments. The number of terms to define increases to 85 in TAP 2, where some terms-like "lesson plan" and “objective" - are repeated from TAP 1. New terms, like "achievement gap," are introduced, along with a series of teaching related and student related factors that are identified as 
contributors to this gap. While some TAP 2 standards call for a review of legislation and court cases, others ask students to define specific legislation; for example, students must define the Family Educational Right and Privacy Act as “a federal law that protects a student's education records." Both the TAP 1 and TAP 2 standards include a separate list of vocabulary on the final page of each document.

TAP 3 deviates from the vocabulary emphasis of the first two sets of standards. The standards do include a vocabulary list of 56 words, once again repeating words also listed in the previous standards while introducing new words (e.g., "data," "home school"). Although the words listed in the vocabulary list are threaded throughout the TAP 3 standards, the emphasis on providing fixed definitions of the terms is not as explicit as it is in the previous courses. The terms are not listed in bold, and, although they are sometimes couched in behaviorist objectives (e.g., "Students will learn to use assessment and interpret data for the purpose of making decisions that will advance teaching and learning."), the word define (or any derivative of define) does not appear in the standards. Despite this change, there is a very clear emphasis for students across the standards on developing a standardized vocabulary for education and teaching.

\section{Understanding Teaching as a Cycle with Measurable Outcomes}

Not only do the standards seem to demand a standardized language concerning education and teaching, but they also appear to prioritize a particular framework for instruction. Standard 2 of the TAP 3 standards, "Understand instruction and assessment cycle," explicitly describes instruction as a five-step process, including planning, teaching, assessing, reflecting, and adjusting. Students exploring teaching in the class are expected to outline curricular goals and objectives, develop formative and summative assessments that produce data, and then analyze and interpret data. Although implicit in one of the TAP 2 standards, where students are expected 
to "[r]eflect on improvement plans based on results of assessment," instructional data analysis is heavily emphasized in the TAP 3 standards. As part of this final course, students are required to track student performance, identify patterns and trends, identify areas for remediation, modify instructional strategies or approaches, and ultimately use data to determine whether an assessment given to students was effective. Teaching, in the view of the standards, is a datadriven process, which students must learn about, and eventually learn to implement on their own.

This results-oriented focus for teaching and learning in the TAP standards is also present in documents created by the Educators Rising organization with which the State of Utah has partnered. The introduction of Educators Rising's standards also depict teaching as a cycle of planning, teaching, assessing, and reflecting, an overarching view that filters into the individual standards created by the organization. For example, Standard VI calls for students to "learn to use assessments and interpret data," the purpose of which is to "mak[e] decisions that will advance teaching and learning." The following standard targets reflective practice, indicating that students should "learn how reflective practice enables them to advance student learning and grow professionally." Much like Utah's TAP standards, the Educators Rising standards position learning as a finite and observable process, one in which assessment data must dictate teachers' instructional decision-making.

It is unclear whether the Educators Rising standards were directly tapped to create the TAP courses, but the similarities in the standards' characterizations of teaching as a finite and observable process are both remarkably similar to the ways in which Educators Rising's parent organizations portray teaching and learning. PDK International lists results among its core values, which "matter, both for ourselves and for public schools." Improvement in public schools, according to PDK International, requires accountability, as well as "results-based 
practices." Curriculum Management Solutions, Inc.'s web site is more direct in its advocacy of results-oriented teaching and learning, identifying the primary goal of the organization as "provid[ing] districts with reports, data, recommendations, and training that, when implemented, will improve student achievement and the overall quality of student learning." PDK International's and Curriculum Management Solutions, Inc.'s stated goals or overarching missions make it unsurprising to see similar references in the Educators Rising standards.

Embedded in the instructional cycle is a privileging of certain psychological theories and/or educational practices related to psychology. In the TAP standards, the privileging of psychological theories is most obvious in TAP 2. This particular course includes an examination of various psychologists and their learning theories, including Piaget's theory of cognitive development, Maslow's hierarchy of needs, and Erikson's stages of psychosocial development. Students are expected to "explore applications for learning for each theory," yet the specific application to practice is not as obvious as the use of planning approaches like creating measurable objectives. Objectives are an aspect of all three TAP courses, as well as the Educators Rising standards. Although objectives are not tied to a specific theorist or theory, their use in Utah's TAP standards parallels Tyler's (1949/2013) principles of curriculum and instruction. Tyler (1949/2013) positioned objectives as "educational ends" or "results to be achieved from learning" (p. 37), which descended from what Tyler called a psychology of learning. The development of objectives plays a central role in the courses, as Utah's theory of teaching relies on teachers' abilities to define and measure learning outcomes.

\section{Producing Teaching Materials}

To define and measure learning outcomes, students also must develop some familiarity with the production of instructional materials like assessments. Assessment is another 
instructional element that appears across all three TAP courses. In the first course, students must define what summative assessments and competencies are. Additional definitions are included in TAP 2, such as standards-based assessment and formative assessment. TAP 3 adds diagnostic assessment, but also demands that students be able to create, modify, and administer various types of assessments, including a 10-question quiz. The Educators Rising standards also demand the production of assessments through the acquiring of what the standards call "assessment literacy," which includes teachers' abilities to select, create, modify, and administer assessments, along with "modifications and accommodations made to meet students' cognitive, social, emotional, and physical needs." Interestingly, the Educators Rising standards mention a portfolio-based assessment that the organization conducts, yet the standards — as well as Utah's TAP standards — do not require students to develop "assessment literacy" with authentic assessments.

Another teaching material that is repeatedly referenced in the documents related to Utah's teacher career exploration courses is lesson plans. The instructional cycle, according to Educators Rising's standards, requires "well-designed" plans that include attempts to "differentiate instruction and scaffold learning." TAP 2 calls for the identification of lesson plan components, mostly by defining vocabulary words, but the emphasis shifts in TAP 3 to creating plans. For the course's capstone project, students must create a unit plan in a teaching area of their interest that consists of "a variety of lesson plans." Neither set of standards mandates a particular lesson plan format or template (e.g., Understanding by Design).

However, the capstone unit plan requires the production of a number of other documents, some of which are unrelated to the instructional cycle detailed across the various standards. Additional elements the unit "will include" are a pre/post test, classroom management plan, 
substitute plan, emergency plans, formative assessments, and data assessment/analysis. In addition, technology is identified as something that needs to be included in the unit plan, though the form technology must take is not stipulated in the TAP 3 standards. There is a clear indication from TAP 3's capstone project, as well as other performance skills across the three classes like creating resumes and artifacts related to culture biases, that becoming a teacher in large part means developing proficiency in creating these materials.

By encouraging involvement with Educators Rising, the TAP curriculum developers indirectly promote a view of teacher learning in which teaching artifacts are produced for external review. Educators Rising emphasizes what it calls "fundamental teaching practices that are critical for high school students to develop" through the earning of micro-credentials, an approach also used with professional educators whereby educators demonstrate proficiency in a chosen topic or skill via external document or portfolio review (Tooley \& Hood, 2021). Partnering with Digital Promise, a business entity that specializes in micro-credentials, Educators Rising markets five "Beginning to Teach" micro-credentials, which cost between $\$ 35$ and $\$ 45$ to earn: 1) targeting skills like anti-bias instruction; 2) developing classroom culture; 3) collaboration; 4) formative assessment; and 5) enhancing learner engagement. According to Educators Rising, micro-credentials represent "a meaningful early step on the path to accomplished teaching," which Educators Rising — and presumably the TAP curriculum developers - hopes that higher education institutions, employers, and other entities will "recognize and value."

\section{Cultivating (Discrete) Teaching Skills}

Through the promotion of teaching as a fixed cycle and the production — and sometimes external review of - teaching materials, the TAP courses frame teacher learning as the cultivation 
of certain skills related to teaching, another set of needs identifiable across documents analyzed in this study. Each of the elements found in the instructional cycle could constitute a discrete teaching skill to learn. For example, the TAP standards include standards focused on creating assessments, which includes the outlining — and likely the drafting — of educational objectives, along with the creation of assessments themselves, among other elements. Data analysis includes its own series of subskills, such as tracking performance, identifying patterns and trends, and modifying teaching approaches based on data and analysis. In addition, the standards divide learning to teach into several skills, like "Build formal and informal content knowledge" and "Identify the different social, cultural, ethnic, and economic backgrounds in local communities." Many of these subskills descend from the characterization of teaching as a cycle with fixed steps or elements.

In other cases, the teaching skills not only descend from the standards' instructional cycle but also parallel Utah frameworks for teaching for the state's professional educators. As part of TAP 3, students are asked to '[i]dentify strategies to adapt to student learning," which evidently involves categorizing these strategies in three tiers: 1) "Tier 1 - best practice; whole class instruction"; 2) "Tier 2 - small group reteaching"; and 3) "Tier 3 - remediate and differentiate; one-on-one." The three tiers parallel the Utah Multi-Tiered System of Supports (MTSS), which the state describes as a framework "for implementing systemic, evidence-based practices to maximize student achievement in academics and behavior in preparation for and leading to College and Career Readiness.” MTSS includes three tiers of instruction, including instruction using evidence-based practices for all students, targeted instruction for students "who have not responded sufficiently to Tier 1 content instruction," and intensive, "individually-responsive instruction and supports" for students with specific needs. Much like the TAP standards, MTSS 
emphasizes the use of multiple data points and data-based decision-making and instructional changes. The overlap between documents like the TAP standards and the MTSS framework clearly demonstrate the State of Utah's efforts to introduce students interested in education or teaching careers to the instructional imperatives the state requires of professional educators.

The cultivation of skills is framed as a way to acclimate to Utah's instructional expectations and frameworks for professional educators, as well as a way to market oneself through the earning of different credentials. Utah's CTE appears to market various career clusters - its Education \& Training Career Cluster as well as others - using student quotes on its web site emphasizing the "skills that [students] can apply in life" and "in the workforce." Through the successful completion of a skill assessment at the end of the TAP courses, students can earn a CTE skill certificate; the CTE advertises on its web site that more than 12,000 CTE skill certificates have been awarded to students in the Education \& Training Career Cluster alone. Microcredentials offered by DigitalPromise and promoted in Educators Rising activities fulfill a similar role in students' preparation, fragmenting teacher learning into individual skills allegedly accrued through the production of teaching materials and external review.

Not all skills outlined in the TAP standards are related to teaching and education; some might be considered soft skills that can be utilized in an array of professional jobs and settings. Utah's CTE Career Pathways encourage the cultivation of opportunities that allow students to "learn how to become productive employees and gain the academic skills to increase their earning potential." Such learning and skill development is embedded in the TAP standards as well. For example, the TAP 1 standards include an interview with a current administrator or teacher regarding their role's benefits; students are required in the standards to "email the professional to set up an appointment, conduct the interview using professional employability 
skills, and follow-up with a handwritten thank you note to the professional." Later in TAP 3, students are asked to "[d]evelop and practice a professional mindset to enhance student learning," including “internaliz[ing] critical questions about their teaching" and "actively seeking opportunities to work together." Although TAP 3 's expectations are more closely coupled to professional teaching expectations and norms, the emphasis on soft, transferable employment skills can be seen across the TAP standards.

\section{Identifying Difference}

Educators Rising's anti-bias instruction micro-credential reflects a relative need present in Utah's teacher career exploration courses: the ability to identify difference. Diversity and multiculturalism are elements of all three $T A P$ courses. In $T A P 1$, students are expected to define diversity and multiculturalism, culminating in the creation of a children's picture book "that explores diversity and/or special populations in a way that reinforces multiculturalism and diversity." By the time students reach TAP 3, they must show that they "learn about themselves and their students," including discussions of "cultural competences, positive responses to students' individual needs, and promot[ing] student voice." Much like the instructional cycle, engagement with diversity is broken into a series of discrete subskills that students must identify and discuss.

Although the standards call for the identification of diverse backgrounds and discussions of cultural competencies, they offer little guidance concerning the unique backgrounds and competencies Utah students may hold or require, as well as the influences of these backgrounds and competencies on teaching and learning. The standards do not reference the diverse and divergent groups that live in Utah, including its major Native American tribes and its nearly $62 \%$ Mormon population (Associated Press, 2018, December 16). Diverse backgrounds and cultural 
competencies — and their impact on teaching — are essentially distilled into discrete and generic skills for students to memorize, recall, and discuss.

\section{Discussion and Implications}

Drawing from the TAP strands and standards documents, along with documents, web sites, and videos from supporting organizations like Educators Rising and its parent entities, this study sought to surface the perceived and relative teacher learning needs Utah's curriculum developers appear to hold for secondary students interested in teaching and education careers. The study found that the state has framed the courses around six central needs for such students: 1) learning about the teaching profession; 2) developing a standardized vocabulary for education and teaching; 3) understanding teaching as a cycle with measurable outcomes; 4) producing teaching materials; 5) cultivating teaching skills, and 6) identifying difference in/between students. Utah's TAP courses are not always offered at secondary schools, yet when they are they form a frontier form of teacher education.

These central needs evident in the TAP courses appear to be an attempt to reorient anticipatory socialization and teacher professionalization through the commodification of teacher learning. By promoting a standardized vocabulary and fixed, cyclical view of teaching, the TAP courses appear to create "a specialized body of knowledge" a teacher must be trained and socialized into to become a professional (Werler, 2016, p. 64; see also Lortie, 1975/2002). This (re)socialization of TAP students is conducted through the memorization of vocabulary and normative teaching model but also through the production of documents and the procurement of microcredentials, all of which serve as tools as curriculum developers reorient teacher learning as an instrumental process (Werler, 2016). Thus, secondary students are transformed by TAP courses into consumers. Instead of a complex, non-linear, and personal form of learning 
occurring across a continuum of experiences (Greene, 1978; Feiman-Nemser, 2001; Strom, 2015), learning to teach within the TAP courses is a commodity that can be transmitted and even purchased (Saunders, 2007; Werler, 2016).

Ostensibly the TAP courses are to recruit young people into the teaching profession, yet the courses appear to have other aims related to employability and expectations. Introducing secondary students to particular roles and expectations for the teaching profession may serve as a special facilitator for entry into the profession; by socializing secondary students into professional roles and expectations, the hope may be to help students evaluate teaching as a possible career, during a period when emotional experiences may spark an intense interest in particular careers (Lortie, 1975/2002). However, the related emphasis on college and transferrable soft skills observed in some pre-collegiate GYO programs (e.g., Bianco, 2009) is indicative of a form of commodification noted in higher education institutions, where an intense focus on soft skills has been utilized to help students to quickly graduate and move into jobs (Baltodano, 2012). To place oneself on the road to becoming a professional teacher, TAP students enter the educational marketplace to develop a particular skill set privileged by the TAP courses, Educators Rising, and Digital Promise. This pathway towards becoming a professional teacher ignores — or at least obscures - two important considerations.

First, characterizing learning to teach as the acquisition of skills ignores the complex, personal nature of what it is to learn to teach. The TAP standards only briefly allude to the power of personal histories and biographies, yet these histories and the particular experiences that form them have been found to be consequential for education students (Davis, 2021a; Greene, 1978). Recent scholarship has described learning to teach as a complex process or system, one that draws from preservice teacher preparation but also beliefs, experiences, influential individuals, 
curriculum, school characteristics, understanding of the influence of race and poverty on education, and other factors (Davis, 2021a; Ell et al., 2017; Milner IV \& Howard, 2013; Strom, 2015). Rather than engage with this complexity, the TAP curriculum attempts to overlay vocabulary and skills that might constitute an attempt to develop some semblance of a shared technical culture for Utah teachers. The emphasis in the standards is identifying the vocabulary and skills to be transmitted to students.

Second, even if this transmission is deemed significant by teacher education stakeholders, the TAP standards do not appear to function as part of a continuum of learning experiences for teachers. Much like Audrain and Googin's (2019) recommendations for teacher academies, which include the use of the Educators Rising standards as well as the AACTE's Clinical Practice Commission report, the TAP standards appear to map backwards from professional expectations for teachers. This backwards mapping is a sensible approach for curriculum development, yet it ignores the reality of teacher learning and preparation: most teachers continue their learning and preparation in college/university teacher preparation programs (Partelow, 2019, December 3), particularly in Utah, which has recently experienced a 65\% increase in teacher preparation program enrollments (Camera, 2019, December 3). If the TAP standards and classes are not situated as part of the continuum of learning experiences for teacher professional learning (see Feiman-Nemser, 2001), there is a risk that the learning done in the TAP classes may have limited significance in college/university teacher preparation programs. College/university teacher educators may use a wide array of theoretical frames and commitments to conceptualize the teacher learning needs of preservice education students, defining terms differently and identifying disparate skills as significant in teacher learning.

One must consider whether the disconnect from or ignoring of college/university-based 
teacher preparation programs is intentional. Outside of the Utah CTE office, it is unclear who else may be responsible for the development of the TAP standards, and/or whether college/university teacher educators are involved in the process at all. Educators Rising's standards document is clearer about the composition of the development team; the Educators Rising standards committee and staff do not appear to include a single college/university-based teacher educator. Promoting the cultivation of soft skills and employment, characterizing teaching as a narrow technical activity with a specific vocabulary and skill/document set, and creating a market for credentialing all frame teacher learning as an activity dictated by neoliberal impulses and top-down government directives (Jess et al., 2021; Werler, 2016). These directives position the prospective teacher as "a market-oriented customer of learning opportunities" (Werler, 2016, p. 69). By commodifying teacher learning and preparation in these ways, it might be concluded the TAP standards present an effort to kill two birds with one stone: to produce workers for the economy, particularly the teaching profession, while also pressuring teacher education and further challenging the monopoly of colleges/universities on teacher preparation (Zeichner, 2010).

This indictment, while concerning, must be tempered by the limitations of the present study. The focus of this study was the TAP standards, and any resources related to the development or implementation of these courses. However, the documents analyzed in this study did not include the actual implementation of the TAP standards in secondary schools. Future studies might focus on the ways in which these standards are used in this frontier form of teacher education, particularly by secondary teachers interpreting the standards as they serve as frontline teacher educators. Analyzing Utah's TAP standards does not tell the field about teacher recruitment and education initiatives in other states, such as teacher academies, yet the needs 
analysis approach utilized in this study offers a method to analyze curriculum standards and artifacts, and perhaps compare curricula and initiatives between states. The role of state CTE offices in high school teacher career exploration courses, as well as Educators Rising's roleboth in conjunction with CTE offices as well as independently_-are both important threads for researchers to examine, yet in this study they were primarily analyzed through their connection to the TAP standards and courses.

A final theoretical limitation of this study presents another line of inquiry for researchers to pursue. One way to combat the top-down, market-based view of teacher learning identified by this study is for high school and college/university-based teacher educators to become more sensitive to what pre-collegiate students learn about teaching. By studying pre-collegiate students' experiences with teachers and teaching — and in the process moving beyond old framings of such learning (e.g., Lortie's 1975/2002 apprenticeship of observation), an argument could be crafted concerning the unique nature of pre-collegiate teacher learning. Although the present study focused on curricular artifacts, the notion of felt needs (e.g., Berwick, 1989) provides one possible analytical frame to examine student perspectives on teacher learning. Studies of pre-collegiate students and teacher learning are rare (but see Davis, 2021a; Wilson \& Corbett, 2001), yet they present important perspectives on what pre-collegiate students think about and know of teaching (Davis, 2021b), which might be instrumental in making teacher career exploration courses responsive to students' learning needs as prospective teachers. 


\section{References}

Adams, E. (2021). Being before: Three Deleuzian becomings in teacher education. Professional Development in Education, 47, 2-3, 392-405. https://doi.org/10.1080/19415257.2021.1891954

Aguilar, M. (2020, February 4). Addressing Utah's teacher shortage. Retrieved July 20, 2020 from https://attheu.utah.edu/facultystaff/addressing-utahs-teacher-shortage/

Associated Press. (2018, December 16). New figures show lower percentage of Mormons in Utah's biggest county. Boston Globe. https://www.bostonglobe.com/news/nation/2018/12/16/new-figures-show-fewermormons-utah-biggest-county/yU7IHb9Qsz9GcDRJVwQ2aI/story.html

Auck, N., \& Suddreth, D. (2019). The Utah State Board of Education report to the Public Education Appropriations Subcommittee: Concurrent enrollment. https://www.schools.utah.gov/file/0c44d684-d5ff-4da0-997e-26d37d0328a7

Audrain, R.L., \& Googins, J. (2020). Beyond teaching teddy bears: Generating and sustaining high school students' interest in the teaching profession through clinical practice. https://www.researchgate.net/profile/R-LennonAudrain/publication/347796543_Beyond_Teaching_Teddy_Bears_Generating_and_Sust aining_High_School_Students'_Interest_in_the_Teaching_Profession_through_Clinical_ Practice/links/607d99052fb9097c0cf72a1f/Beyond-Teaching-Teddy-Bears-Generatingand-Sustaining-High-School-Students-Interest-in-the-Teaching-Profession-throughClinical-Practice.pdf 
Baltodano, M. (2012). Neoliberalism and the demise of public education: The corporatization of schools of education. International Journal of Qualitative Studies in Education, 25(4), 487-507. https://doi.org/10.1080/09518398.2012.673025

Barry, B., \& Shields, P.M. (2017). Solving the teacher shortage: Revisiting the lessons we've learned. Phi Delta Kappan, 98(8), 8-18. https://doi.org/10.1177/0031721717708289

Berwick, R. (1989). Needs assessment in language programming: From theory to practice. The Second Language Curriculum, 6(2), 48-68.

Bianco, M., \& Marin-Parris, D. (2019). Pathways2Teaching: Addressing the teacher diversity gap through a grow your own program. Teaching Exceptional Children, 52(1), 38-40. https://doi.org/10.1177/0040059919875704

Birks, M., Chapman, Y., \& Francis, K. (2008). Memoing in qualitative research: Probing data and processes. Journal of Research in Nursing, 13, 68-75. https://doi.org/10.1177/1744987107081254

Bolich, A. M. (2003). Spinning our wheels: Minority teacher supply in SREB states. Washington, DC: Southern Regional Education Board. https://files.eric.ed.gov/fulltext/ED475316.pdf

Bowen, G.A. (2009). Document analysis as a qualitative research method. Qualitative Research Journal, 9(2), 27-40. https://doi.org/10.3316/QRJ0902027

Boz, N., \& Boz, Y. (2008). A qualitative case study of prospective chemistry teachers' knowledge about instructional strategies: Introducing particulate theory. Journal of Science Teacher Education, 19(2), 135-156. https://doi.org/10.1007/s10972-007-9087-y

Camera, L. (2019, December 3). Sharp nationwide enrollment drop in teacher prep programs cause for alarm. US News \& World Report. https://www.usnews.com/news/education- 
news/articles/2019-12-03/sharp-nationwide-enrollment-drop-in-teacher-prep-programscause-for-alarm.

Cancino, M., Durán, M., \& Solorza, C. (2020). What learning can do to teaching: Assessing the impact of apprenticeship of observation on pre-service teachers' beliefs. English Teaching \& Learning, 44, 297-312. https://doi.org/10.1007/s42321-019-00044-Z

Carver-Thomas, D., Leung, M., \& Burns, D. (2021). California teachers and COVID-19: How the pandemic is impacting the teacher workforce. Learning Policy Institute. https://learningpolicyinstitute.org/sites/default/files/productfiles/California_COVID_Teacher_Workforce_REPORT.pdf

Collet, V.S., \& Greiner, A.C. (2020). Revisioning grammar instruction through collaborative lesson study: A new apprenticeship of observation. Literacy Research \& Instruction, 59(2), 95-120. https://doi.org/10.1080/19388071.2019.1709927

Davis, W.J. (2021a). A new teacher education frontier: Understanding high school students' conceptions of teaching [Manuscript submitted for publication]. Department of Teacher Education, Southern Utah University.

Davis, W.J. (2021b). Recruitment of teachers of color: On "gifts and talents." Kappa Delta Pi Record, 57(2), 52-54. https://doi.org/ 10.1080/00228958.2021.1890436

Douglas, A.S. (2019). Learning to teach: A focus on the personal rather than the technical aspects of teacher education. Teacher Education Advancement Network Journal, 11(1), 71-83. https://files.eric.ed.gov/fulltext/EJ1268223.pdf

Durand, T. M., \& Tavaras, C. L. (2020). Countering Complacency With Radical Reflection: Supporting White Teachers in the Enactment of Critical Multicultural Praxis. Education and Urban Society. https://doi.org/10.1177/0013124520927680 
Ell, F., Haigh, M., Cochran-Smith, M., Grudnoff, L., Ludlow, L., \& Hill, M.F. (2017). Mapping a complex system: What influences teacher learning during initial teacher education? Asia-Pacific Journal of Teacher Education. http://dx.doi.org/10.1080/1359866X.2017.1309640

Feiman-Nemser, S. (2001). From preparation to practice: Designing a continuum to strengthen and sustain teaching. Teachers College Record, 103(6), 1013-1055. http://bir.brandeis.edu/handle/10192/33196

García, E., Weiss, E. (2019). The teacher shortage is real, large and growing, and worse than we thought. Economic Policy Institute. https://files.eric.ed.gov/fulltext/ED598211.pdf

Gecker, J. (2021, September 22). COVID-19 creates dire US shortage of teachers, school staff. US News \& World Report. https://www.usnews.com/news/business/articles/2021-0922/covid-19-creates-dire-us-shortage-of-teachers-school-staff

Gist, C.D., Bianco, M., \& Lynn, M. (2019). Examining grow your own programs across the teacher development continuum: Mining research on teachers of color and nontraditional educator pipelines. Journal of Teacher Education, 70(1), 13-25. https://doi.org/10.1177/0022487118787504

Goings, R.B., \& Bianco, M. (2016). It's hard to be who you don't see: An exploration of black male high school students' perspectives on becoming teachers. The Urban Review, 48(4), 628-646. https://doi.org/10.1007/s11256-016-0371-z

Goldhaber, D., \& Theobald, R. (2021). Teacher attrition and mobility over time. Educational Researcher. https://journals.sagepub.com/doi/full/10.3102/0013189X211060840?casa_token=sd- 
mqOJJVqQAAAAA:BluaakNv6fKzCGcZGoehGJexWmJpxKifz2H6irvEAfBnZ7X2hT W7by2ff1mXJRCyzlDPaNhUtA9xaA

Gray, P.L. (2020). Mitigating the apprenticeship of observation. Teaching Education, 31(4), 404423. https://doi.org/10.1080/10476210.2019.1631785

Greene, M. (1978). Teaching: The question of personal reality. Teachers College Record, 80(1), 23-32. https://www.tcrecord.org/books/Content.asp?ContentID=1080

Hargreaves, A., \& Fullan, M. (2020). Professional capital after the pandemic: Revisiting and revising classic understandings of teachers' work. Journal of Professional Capital and Community, 5(3-4), 327-336. https://doi.org/10.1108/JPCC-06-2020-0039

Holt-Reynolds, D. (1992). Personal history-based beliefs as relevant prior knowledge in course work. American Educational Research Journal, 29(2), 325-349. https://doi.org/10.3102/00028312029002325

Iwai, T., Kondo, K., Lim, D. S., Ray, G., Shimizu, H., \& Brown, J. D. (1999). Japanese language needs analysis 1998-1999. https://scholarspace.manoa.hawaii.edu/bitstream/10125/8950/NW13.pdf

Jess, M., McMillan, P., Carse, N., \& Munro, K. (2021). The personal visions of physical education student teachers: Putting the education at the heart of physical education. The Curriculum Journal, 32(1), 28-47. https://doi.org/10.1002/curj.86

Kaewpet, C. (2009). A framework for investigating learner needs: Needs analysis extended to curriculum development. Electronic Journal of Foreign Language Teaching, 6(2), 209220. https://citeseerx.ist.psu.edu/viewdoc/download?doi=10.1.1.525.3928\&rep=rep1\&type=pd $\underline{\mathrm{f}}$ 
Kettner, P.M., Moroney, R.M., \& Martin, L.L. (2008). Designing and managing programs: An effectiveness-based approach (2nd ed.). Thousand Oaks, CA: SAGE Publications

Knapp, N.F. (2012). Reflective journals: Making constructive use of the "apprenticeship of observation" in preservice teacher education. Teaching Education, 23(3), 323-340. https://doi.org/10.1080/10476210.2012.686487

Lortie, D. C. (2002). Schoolteacher: A sociological study (2nd Ed.). Chicago, IL: University of Chicago Press. (Original work published 1975)

McGloin, S. (2008). The trustworthiness of case study methodology. Nurse researcher, 16(1), 45-55. https://doi.org/10.7748/nr2008.10.16.1.45.c6752

Mewborn, D.S., \& Tyminski, A.M. (2006). Lortie's apprenticeship of observation revisited. For the Learning of Mathematics, 26(3), 30-32. https://www.jstor.org/stable/40248547

Miles, M. B. \& Huberman, A. M. (1994). Qualitative data analysis (2nd ed.). Thousand Oaks, CA: SAGE.

Milner IV, H.R., \& Howard, T.C. (2013). Counter-narrative as method: Race, policy and research for teacher education. Race Ethnicity and Education, 16(4), 536-561. https://doi.org/10.1080/13613324.2013.817772

Partelow, L. (2019). What to make of declining enrollment in teacher preparation programs. Center for American Progress. https://www.americanprogress.org/article/make-decliningenrollment-teacher-preparation-programs/

Recruiting New Teachers. (1993). Teaching's next generation: A national study of precollegiate teacher recruitment. DeWitt Wallace-Reader's Digest Fund and Recruiting New Teachers, Inc. https://files.eric.ed.gov/fulltext/ED364523.pdf 
Saldaña, J. (2016). The coding manual for qualitative researchers (3rd ed.). London, United Kingdom: SAGE Publications Ltd.

Saunders, D. (2007). The impact of neoliberalism on college students. Journal of College and Character, 8(5), 1-9. https://doi.org/10.2202/1940-1639.1620

Shulman, L. S. (1987). Knowledge and teaching: Foundations of the new reform. Harvard Educational Review, 57(1), 1-21.

Smagorinsky, P., \& Barnes, M.E. (2014). Revisiting and revising the apprenticeship of observation. Teacher Education Quarterly, 41(4), 29-52. https://www.jstor.org/stable/10.2307/teaceducquar.41.4.29

Smith, M., \& Ho, S. (2019, August 23). Teacher shortage, protests complicate educator pay dynamics. US News \& World Report. https://www.usnews.com/news/politics/articles/2019-08-23/teacher-shortage-protests$\underline{\text { complicate-educator-pay-dynamics }}$

Stake, R.E. (1995). The art of case study research. Thousand Oaks, CA: SAGE Publications.

Strom, K.J. (2015). Teaching as assemblage: negotiating learning and practice in the first year of teaching. Journal of Teacher Education, 66(4), 321-333. https://doi.org/10.1177/0022487115589990

Sumarsono, D., Bagis, A.K., \& Arrafii, A. (2017). Students' needs to develop English writing materials. Lingua Cultura, 11(2), 67-71. https://doi.org/10.21512/lc.v11i2.1504

Sutcher, L., Darling-Hammond, L., \& Carver-Thomas, D. (2019). Understanding teacher shortages: An analysis of teacher supply and demand in the United States. Education policy analysis archives, 27(35). https://files.eric.ed.gov/fulltext/EJ1213618.pdf 
Tooley, M., \& Hood, J. (2013). Harnessing micro-credentials for teacher growth: A national review of early best practices. New America. https://files.eric.ed.gov/fulltext/ED612409.pdf

Tyler, R.W. (2013). Basic principles of curriculum and instruction. Chicago, IL: The University of Chicago Press. (Original work published 1949)

Werler, T. (2016). Commodification of teacher professionalism. Policy Futures in Education, 14(1), 60-76. https://doi.org/10.1177/1478210315612646

Wilson, B.L., \& Corbett, H.D. (2001). Listening to urban kids: School reform and the teachers they want. State University of New York Press.

Zeichner, K. (2010). Competition, economic rationalization, increased surveillance, and attacks on diversity: Neo-liberalism and the transformation of teacher education in the U.S. Teaching and Teacher Education, 26, 1544-1522.

https://doi.org/10.1016/j.tate.2010.06.004 